Corresponding Author.

email address : nr.karin4@gmail.com

Karina Nur Ramadhanintyas

Received : 2 Februari 2020

Revised : 5 maret 2020

Accepted : 3 April 2020

\title{
HUBUNGAN MENGONSUMSI MAKANAN KARIOGENIK DENGAN KEJADIAN KARIES PADA ANAK USIA SEKOLAH DI MI AL-HIDAYAH Karina Nur Ramadhanintyas ${ }^{1}$, Maria Ulfa ${ }^{2}$, Vika Ayu Budiani ${ }^{3}$
}

\author{
${ }^{1,3^{*}}$ STIKES Bhakti Husada Mulia Madiun \\ ${ }^{2^{*}}$ STIKES Cendekia Utama Kudus \\ Email : nr.karin4@gmail.com
}

\begin{abstract}
ABSTRAK
Karies gigi sering terjadi pada anak sekolah dasar yang disebabkan karena kebiasaan mengonsumsi makanan kariogenik. Kebiasaan anak senang mengkonsumsi makanan kariogenik, karena memiliki rasa yang manis dan enak. Karies gigi adalah suatu penyakit jaringan keras gigi (email, dentin). Tujuan dari penelitian ini adalah untuk mengetahui Hubungan Kebiasaan Mengonsumsi Makanan Kariogenik Dengan Kejadian Karies Gigi. Metode penelitian ini menggunakan desain korelasi dengan pendekatan cross sectional. Populasi penelitian sejumlah 105 siswa kelas I dan II, sampel penelitian 51 siswa yang giginya belum mengalami gigi lepas yang diambil dengan metode simple random sampling. Uji statistik yang digunakan adalah uji Spearman Rank. Dari hasil penelitian diperoleh responden yang sering mengkonsumsi makanan kariogenik sebanyak 28 siswa (54,9\%). Responden yang terjadi karies gigi sebanyak 37 siswa $(72,5 \%)$ dan responden yang tidak terjadi karies gigi sebanyak 14 siswa $(27,5 \%)$. Hasil uji Spearman diperoleh nilai p-value $=0,000$ sehingga Hipotesa alternatif diterima. kesimpulan bahwa Ada Hubungan Kebiasaan Mengonsumsi Makanan Kariogenik dengan Kejadian Karies Gigi. Dari penelitian ini bahwa mengkonsumsi makanan kariogenik dapat menyebabkan terjadinya karies gigi. Disarankan untuk mengurangi konsumsi makanan kariogenik (permen, coklat, es krim dan biskuit) dapat menekan angka terjadinya karies gigi di MI AL-Hidayah Madiun.
\end{abstract}

Kata Kunci : Makanan Kariogenik, Karies Gigi, Spearman

\begin{abstract}
Teeth caries common in primary school children are caused by cariogenic food consumption habits. The children like to cousume cariogenik food, because it has a sweet and tasty. Dental caries is a disease of dental hard tissue (email, dentin). Objective of this study was to determine the relationship Cariogenik Consumption Eating Relations With Caries In School Age Children. This study uses correlation design with cross sectional approach.
\end{abstract}

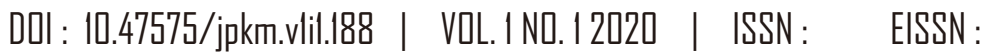


The study population are 105 students in grade I and II, sample 51 students whose teeth have not experienced loose teeth taken by simple random sampling method. The statistical test used the Spearman test.The results of this study showed respondents who frequently consume cariogenic foods as are 28 students (54.9\%). Respondents who have dental caries are 37 students $(72.5 \%)$ and respondents who did not happen dental caries are 14 students $(27.5 \%)$. Results obtained spearman test $\mathrm{p}$-value $=0.000$ so that the alternative hypothesis is accepted. the Conclusion of this study, there is relationship between cariogenik consumption with caries is habits and caries. The from this study that the cariogenic foods can cause dental caries. So less consumption of cariogenic foods (candy, chocolate, ice cream and biscuits) can reduce the number of dental caries in MI AL-Hidayah Madiun.

\section{Keywords : Food cariogenic, Dental Caries, Spearman}

\section{PENDAHULUAN}

Gigi merupakan satu kesatuan dengan anggota tubuh kita yang lain. Kerusakan pada gigi dapat mempengaruhi kesehatan anggota tubuh lainnya,sehingga akan mengganggu aktivitas sehari-hari. Salah satu faktor yang dapat merusak gigi adalah makanan dan minuman,yang mana ada yang menyehatkan dan ada pula yang merusak gigi (Kawuryan, 2016). Karies gigi dapat dialami oleh setiap orang dan dapat timbul pada satu permukaan gigi atau lebih, serta dapat meluas kebagian yang lebih dalam dari gigi, misalnya dari email ke dentin atau ke pulpa. Penyakit karies gigi disebabkan karena banyak hal diantaranya karbohidrat, mikroorganisme, air ludah, permukaan gigi, bentuk gigi (Taringan, 2016).

Karies merupakan penyakit yang banyak menyerang anak-anak, sehingga periode pada anakanak perlu mendapat perhatian khusus, terutama umur 6 sampai 9 tahun dimana umur 6 tahun gigi molar permanen sudah mulai tumbuh sehingga lebih rentan terlebih dahulu terkena karies. Pada usia 9 tahun berlangsung pergantian dari gigi sulung ke gigi permanen, untuk itu kesehatan gigi anak perlu dijaga sejak awal agar anak mempunyai gigi permanen yang baik, sehingga gigi permanen dapat berfungsi sebagaimana mestinya sejak anak-anak sampai seterusnya (Syamsul, 2014).

Kesehatan gigi merupakan masalah kesehatan yang memerlukan penanganan secara komprehensif, karena masalah gigi berdimensi luas yang meliputi:faktor fisik seperti rasa tidak percaya diri ketika adanya warna hitam dibagaian gigi. Faktor sosial ketika diajak berinteraksi tidak dapat menjawab karena mengalami nyeri pada bagaian gigi. Gigi merupakan bagian dari alat pengunyahan padasistem pencernaan dalam tubuh manusia (Worotitjan.,dkk,2013). Karies gigi merupakan salah satu gangguan kesehatan pada gigi yang dapat menyebabkan gigi menjadi keropos, berlubang bahkan patah. Ketidaknyamanan yang dirasakan akibat terjadinya karies gigi juga dapat menghambat asupan makanan didalam tubuh. Kondisi iniakan mempengaruhi pertumbuhan dan perkembangan anak menjadi kurang optimal(Widayati, 2014).

Menurut data World Health Organization (WHO) di dunia tahun 2016, dari 100\% anak usia sekolah $60 \%$ - 90\% mengalami karies gigi. Prevalensi terjadinya karies gigi akan terus meningkat seiring bertambahnya usia. Anak usia 6 (enam) tahun yang telah mengalami karies gigi sebanyak $20 \%$, meningkat $60 \%$ pada usia 8 tahun, $85 \%$ pada 10 tahun dan $90 \%$ pada usia 12 tahun. Hasil Riset Kesehatan Dasar (Rikesdas) 2016 yang diselenggarakan oleh Departemen Kesehatan Republik Indonesia menunjukkan bahwa kerusakan gigi karena karies dialami 72,1\% penduduk Indonesia, dan diantaranya 46,5\% merupakan karies aktif yang tidak mendapatkan perawatan.

Menurut data dari pengurus besar PDGI (Persatuan Dokter Gigi Indonesia) menyebutkan bahwa sedikitnya $89 \%$ penderita gigi berlubang adalah anak-anak usia dibawah 12tahun. Berdasarkan Riset Kesehatan Dasar (RISKESDAS) tahun 2015, anak usia 5-8 tahun memiliki masalah kesehatan gigi dan mulut sebanyak 28,9\%. Anak usia $6-10$ tahun merupakan satu kelompok yang rentan terhadap penyakit gigi dan mulut karena umumnya anak pada umur tersebut masih mempunyai perilaku atau kebiasaan diri yang kurang baik terhadap kesehatan gigi yang menunjukkan bahwa anak pada usia tersebut tingkat kerusakan gigi yang dialami anak cukup tinggi. Menurut data dari kesehatan kota Madiun tahun 2016, jumlah keseluruhan anak 9648, anak yang menderitakaries gigi sejumlah 5274. Menurut data dari sekolahan MI AL Hidayah kota Madiun pada tahun 2018, bahwa anak kelas 1 dan 11 dengan jumlah 105 anak, sebanyak 85 anak diantaranya mengalami karies gigi atau 89\%. 
Beberapa hal yang dapat mempengaruhi terjadinya karies gigi yaitu karena faktor keturunan, ras, jenis kelamin, usia,vitamin, unsur kimia, air ludah plak dan makanan.Jenis makanan yang berdampak pada pembentukan terjadinya karies gigi adalah jenis makanan yang mengandung kariogenik seperti coklat,permen, kuedan makanan manis yang membuat anak-anak sangat rentan terhadap karies gigi. Hal ini dikarenakan makanan yang mengandung karbohidrat misalnya sukrosa dan gula atau makanan yang manis seperti coklat,permen dan kue yang mudah menempel pada gigi yang dapat diragikan oleh bakteri tertentu dan membentuk asam sehingga dapat menjadi plak dan merusak struktur gigi jika dibiarkan begitu saja dalam kurun waktu yang lama (Irma\&Intan, 2013).

Kebiasaan anak senang mengkonsumsi makanan kariogenik, karena memiliki rasa yang manis dan enak. Selain rasanya yang manis dan enak, makanan kariogenik memiliki harga yang murah, mudah di dapatkan, dan dijual dalam berbagai bentuk serta warna makanan yang bervariasi dan disukai anak-anak (cakrawati, 2015).

Karies gigi dapat dicegah agar tidak sampai terjadi keparahan yang lebih luas. Ada berbagai macam cara untuk mencegah karies gigi, antara lain hindari makanan yang mengandung banyak gula, karbohidrat, dan makanan yang mengandung kariogenik, kontrol plak yang ada di gigi dengan cara menggosok gigi setiap hari dua kali per hari atau sesudah makan dan sebelum tidur malam, karena menyikat gigi sebelum tidur berguna untuk menghambat perkembangbiakan bakteri dalam mulut karena dalam keadaan tidur produksi saliva tidak terjadi sehingga banyak sisa makanan yang tertinggal di gigi yang tidak mampu dibersihkan oleh mulut secara alamiah. Jika mulut dalam keadaan kotor, bakteri sangat mudah berkembang biak dan menyebabkan karies gigi, lakukan kumur dengan menggunakan obat kumur, sering periksa ke dokter gigi dan gunakan pasta gigi yang mengandung fluor ( Tarigan, 2016).

Oleh karena itu penulis tertarik untuk melakukan penelitian mengenai hubungan mengkonsumsi makanan kariogenik dengan kejadian karies pada anak usia sekolah di MI AL Hidayah Madiun.

\section{METODE}

Penelitian ini menggunakan jenis penelitian yang bersifat kuantitatif, metode analitik dengan pendekatan Cross Sectional. Populasi dari penelitian ini adalah semua anak kelas I dan II di MI AL Hidayah Kota Madiun sebanyak 105 anak. Besar sampel yang digunakan dihitung dengan rumus slovin yaitu sebanyak 51 siswa, yang ditentukan dengan teknik purposive sampling. Instrumen yang digunakan dalam penelitian kebiasaan mengkonsumsi makanan kariogenik, lembar kuesioner yang berisi 10 pertanyaan responden tentang waktu kebiasaan mengkonsumsi makanan kariogenik dan untuk menilai karies gigi digunakan teknik observasi. Observasi secara langsung dengan melihat kejadian karies yang ada di dalam mulut responden. Analisa univariat peneliti berupa usia, kelas, jenis kelamin. Sedangkan analisa bivariat menggunakan uji Chi-Square.

\section{HASIL DAN PEMBAHASAN}

Pengumpulan data dilakukan 25 Mei 2019 di MI AL-Hidayah Madiun. Data hasil penelitian dikelompokkan kemudian dianalisis dan ditampilkan seperti table dibawah ini :

Tabel 1

Distribusi frekuensi karakteristi responden berdasarkan jenis kelamin

\begin{tabular}{ccc}
\hline Jenis Kelamin & n & \% \\
\hline Laki-laki & 31 & 60,8 \\
Perempuan & 20 & 39,2 \\
Total & 51 & 100 \\
\hline
\end{tabular}

Sumber :Data Primer Diolah, 2019

Peneliti mengatakan bahwa kejadian karies gigi di MI AL-Hidayah terbanyak pada anak berjenis kelamin laki-laki sebanyak 31 siswa $(60,8 \%)$. dengan tanda adanya demineralisasi jaringan karies gigi yang kemudian diikuti kerusakan bahan organik. Terdapat banyak tanda awal pembusukan termasuk adanya bintik putih kapur akan berubah menjadi coklat atau hitam dan pada akhirnya menjadi rongfa atau berlubang di gigi. 
Sebelum rongga terbentuk, proses yang terjadi reversible, namun sekali saja rongga terbentu, maka kerusakan yang terjadi pada gigi yaitu bersifat permanen. Seiring berjalannya proses pembusukan gigi, akan muncul pula rasa sakit dan kematian jaringan gigi. Rasa sakit dapat semakin parah bila gigi terpapar makanan atau minuman panas, dingin, manis atau asam (ADA, 2017)

Tabel 2

Karakteristik Responden Berdasarkan Usia di MI AL-Hidayah Madiun 2019

\begin{tabular}{ccc}
\hline Usia & $\mathbf{n}$ & $\mathbf{\%}$ \\
\hline 6 & 3 & 5,9 \\
7 & 23 & 45,1 \\
8 & 21 & 41,2 \\
9 & 4 & 7.8 \\
Total & 51 & 100 \\
\hline
\end{tabular}

Sumber :Data Primer Diolah, 2019

Responden penelitian ini adalah siswa usia 6-9 tahun. Pada usia sekolah dasar tersebut lebih rentan terjadi karies gigi karena pada umunya anak-anak menyukai makanan yang mengandung gula atau bersifat manis. Gula menjadi nutrisi untuk pertumbuhan bakteri di mulut penyebab karies gigi. Jika gula bergabung dengan plak, maka dalam watu sekitar 20 menit streptococcus mutans di dalam plak akan menghasilkanesponden yang asam (Sariningsih, 2014). Karies gigi dapat dicegah agar tidak sampai terjadi keparahan yang lebih luas. Ada berbagai macam cara untuk mencegah karies gigi, antara lain hindari makanan yang mengandung banyak gula, karbohidrat, dan makanan yang mengandung kariogenik, kontrol plak yang ada di gigi dengan cara menggosok gigi setiap hari dua kali per hari atau sesudah makan dan sebelum tidur malam, karena menyikat gigi sebelum tidur berguna untuk menghambat perkembangbiakan bakteri dalam mulut karena dalam keadaan tidur produksi saliva tidak terjadi sehingga banyak sisa makanan yang tertinggal di gigi yang tidak mampu dibersihkan oleh mulut secara alamiah.

Hasil penelitian serupa yang di lakukan oleh sumarti tahun 2014 di Desa Sekar Kecamatan Gunung pati Semarang menunjukkan bahwa anak usia 6-9 tahun didaerah tersebut mempunyai kebiasaan mengkonsumsi makanan kariogenik yang besar yaitu sebanyak 100 responden yang didapat 88 responden yang memiliki skor mengkonsumsi makanan kariogenik beresiko tinggi mengalami karies gigi dan 12 responden yang memiliki mengkonsumsi makanan kariogenik tidak beresiko mengalami karies gigi. Hal ini menunjukkan bahwa responden yang mengkonsumsi makanan kariogenik beresiko mengalami karies gigi lebih banyak daripada yang tidak beresiko mengalami karies gigi. Dari hasil wawancara kepada orang tua responden, mereka mengatakan bahwa anak-anak mereka rata-rata mengkonsumsi makanan kariogenik lebih dari tujuh kali dalam seminggu (Sumiarti, 2014).

Tabel 3

Kebiasaan Mengkonsumsi Makanan Kariogenik Di MI AL-Hidayah Madiun

\begin{tabular}{|c|c|c|}
\hline $\begin{array}{l}\text { Kebiasaan mengkonsumsi } \\
\text { makanan kariogenik }\end{array}$ & n & $\%$ \\
\hline Tidak & 14 & 27,5 \\
\hline Kadang-kadang & 9 & 17,6 \\
\hline Sering & 28 & 54,9 \\
\hline Total & 51 & 100 \\
\hline
\end{tabular}

Sumber :Data Primer Diolah, 2019

Hasil penelitian pada siswa kelas I dan II MI AL-Hidayah yang berjumlah 51 responden yang frekuensi tidak konsumsi makanan kariogenik berjumlah 14 siswa $(27,5 \%)$ sementara konsumsi makanan kariogenik kadang berjumlah 9 siswa (17,6\%), sedangkan konsumsi makanan kariogenik sering berjumlah 28 siswa (54,9\%). Menurut Tarigan (2013), ada banyak faktor lain yang menyebabkan terjadinya karies gigi selain makanan kariogenik di antaranya keturunan, ras, jenis kelamin, usia, vitamin, unsur kimia, air ludah, mikroorganisme dalam mulut, serta plak. 
Hal ini sejalan dengan penelitian Nuraliyah (2013) dengan judul penelitian "hubungan kebiasaan konsumsi makanan sumber kalsium dengan kejadian karies gigi pada anak sekolah dasar", ia menemukan responden yang sering mengkonsumsi makanan sumber kalsium lebih banyak yang karies $(57,1 \%)$ dari pada yang tidak karies $(42,9 \%)$. Dari penelitian tersebut menunjukan bahwa selain makanan kariogenik ada juga faktor lain yang dapat menyebabkan karies gigi.

Kontrol plak bisa dilakukan dengan menggosok gigi dengan baik dan benar. Plak memiliki konsistensi yang lunak sehingga mudah dibersihkan dengan menggosok gigi yang baik dan benar (Ramadhan, 2010). Hal ini sejalan dengan penelitian Anggraeni (2013) dengan judul penelitian "hubungan antara kebiasaan mengkonsumsi jajanan kariogenik dan menggosok gigi dengan kejadian karies gigi pada anak sekolah", ia menemukan kebiasaan menggosok gigi baik dengan kejadian tidak karies sebanyak 38 responden (53,5\%) e-Journal Keperawatan (e-KP) Volume 4 Nomor 1, Februari 20166 sedangkan menggosok gigi buruk dengan kejadian tidak karies sebanyak 33 responden (46,5\%). Dari penelitian tersebut menunjukan bahwa kebiasaan menggosok gigi yang baik dapat mencegah terjadinya karies gigi meskipun sering mengkonsumsi makanan kariogenik.

Berdasarkan penelitian yang ada peneliti berpendapat bahwa siswa yang lebih sering mengkonsumsi makanan kariogenik lebih banyak mengalami karies gigi dibandingkan siswa yang jarang mengkonsumsi makanan kariogenik. Karena sebagian besar siswa frekuensi mengkonsumsi makanan kariogenik tidak hanya di sekolah saja tetapi juga di rumah, hal ini menunjukan pengulangan konsumsi makanan kariogenik yang terlalu sering akan menyebabkan makanan tersebut akan lama menempel pada gigi sehingga dari waktu ke waktu akan terjadinya karies gigi.

\section{Tabel 4}

Terjadinya Karies Gigi Di MI AL-Hidayah Madiun Tahun 2019

\begin{tabular}{lcc}
\hline \multicolumn{1}{c}{ Jenis Makanan } & n & \% \\
\hline Coklat & 10 & 19,6 \\
Biskuit & 4 & 7,8 \\
Susu & 6 & 11,8 \\
Gulali & 7 & 13,7 \\
Es cream & 12 & 23,5 \\
Permen & 12 & 23,5 \\
Total & 51 & 100 \\
\hline
\end{tabular}

Sumber :Data Primer Diolah, 2019

Kebiasaan mengkonsumsi makanan kariogenik menunjukkan bahwa dari 51 siswa yang diteliti, sebagian besar siswa yang sering mengkonsumsi makanan kariogenik sebanyak 28 siswa (54,9\%). Siswa terbanyak mengkonsumsi makanan permen sebanyak 12 siswa atau $(23,5 \%)$ dan es cream sebanyak 12 siswa atau $(23,5)$.

Anak usia sekolah dasar semakin mandiri sehingga mereka lebih sering mengkonsumsi snack dan makanan ringan lainnya di luar rumah seperti coklat, permen, es krim, kue, roti, susu, biskuit dan makanan manis lainnya dll. Makanan kariogenik seringkali meninggalkan sisa di sela-sela gigi. Sisa makanan yang lama tertinggal menyebabkan resiko terjadinya karies gigi menjadi besar. Gigi yang tidak segera dibersihkan berpengaruh pada produksi bakteri di dalam mulut. Bakteri akan memecah makanan tersebut dan menciptakan suasana asam di dalam mulut hanya dalam waktu 13-20 detik. Faktor lain yang juga menjadi penyebab terjadinya karies pada anak-anak adalah struktur email gigi sulung, lebih tipis dibanding gigi permanen, sehingga proses terjadinya karies pada gigi anak-anak cenderung lebih mudah dan lebih cepat menyebar secaraluas. Selain itu kebiasaan menggosok gigi yang salah juga dapat menyebabkan terjadinya karies gigi (Irma \& Intan, 2013).

Jajan atau snack yang mengandung gula tinggi dan lengket merupakan faktor resiko terjadi karies gigi dan makanan tersebut di sukai oleh hampir semua anak. Setelah makan dan minum jajanan tersebut, anak-anak tidak membersihkan rongga mulutnya sehingga plak dapat dengan mudah terbentuk yang akhirnya menyebabkan karies gigi (taringan, 2016). Hal ini sejalan dengan penelitian yang dilakukan oleh (Saputra, 2010) menyatakan bahwa ada hubungan antara konsumsi makanan kariogenik dan menggosok gigi dengan timbulnya penyakit karies gigi sulung (masing-masing $\mathrm{p}$-value 0,007 dan 0,038). 
Kebiasaan mengkonsumsi makanan kariogenik mempengaruhi timbulnya karies gigi pada anak. Makanan kariogenik seperti coklat,kue, roti, es krim, susu, permen, biskuit dan makanan manis lainnya yang agak lengket dan terbuat dari tepung cenderung mengandung karbohidrat dan sukrosa yang sangat tinggi dan sangat digemari anak apabila terlalu sering dikonsumsi terutama pada waktu senggang makanan tersebut dapat mempengaruhi $\mathrm{pH}$ mulut menjadi lebih rendah sehingga perlu lebih diperhatikan pengaruh substrat kariogenik yang terkandung dalam makanan tersebut sehingga dapat menyebabkan karies gigi (Anita \& Rahayu, 2014). Karies gigi dapat dialami oleh setiap orang dan dapat timbul pada satu permukaan gigi atau lebih, serta dapat meluas ke bagian yang lebih dalam dari gigi misalnya dari email ke dentin atau ke pulpa, salah satu penyebab karies adalah karbohidrat (Tarigan, 2013). Karbohidrat dalam bentuk tepung atau cairan yang bersifat lengket serta mudah hancur di dalam mulut lebih memudahkan timbulnya karies dibanding bentuk fisik lain, karbohidrat seperti ini misalnya kue-kue, roti, es krim, susu, permen dan lain-lain (Suwelo, 1992).

Tabel 5

Terjadinya Karies Gigi Di MI AL-Hidayah Madiun Tahun 2019

\begin{tabular}{ccc}
\hline Karies & $\mathrm{n}$ & $\%$ \\
\hline Ya & 37 & 72,5 \\
Tidak & 14 & 27,5 \\
Total & 51 & 100 \\
\hline
\end{tabular}

Sumber :Data Primer Diolah, 2019

Kejadian karies gigi dari 51 siswa yang diteliti, sebagian besar siswa yang mengalami karies gigi sebanyak 37 siswa (72,5\%). Penyebab karies yaitu bakteri Streptococcus mutans dan Lactobacilli. Bakteri spesifik inilah yang mengubah glukosa dan karbohidrat pada makanan menjadi asam melalui proses fermentasi. Asam terus diproduksi oleh bakteri dan akhirnya merusak sruktur gigi sedikit demi sedikit. Kemudian plak dan bakteri mulai bekerja 20 menit setelah makan (Pratiwi, 2007). penelitian yang dilakukan oleh Alhamda (2011) menyatakan bahwa penyakit gigi dan mulut yang sering ditemukan adalah karies gigi, beberapa faktor yang berhubungan dengan karies gigi adalah makanan yang manis seperti makanan yang mengandung gula.

Hasil pengamatan pada saat melakukan penelitian di lingkungan sekolah juga terdapat kantin yang menjual makanan dan minuman ringan, seperti coklat, permen, gulali, biskui. Siswa-siswi tersebut banyak yang membeli dan mengkonsumsi jajanan dari kantin tersebut. Kejadian karies gigi yang sangat tinggi pada responden sangat mengkhawatirkan karena dapat menimbulkan dampak bagi penderitanya. Anak akan terganggu proses belajar dan sosialisasi dengan teman-temannya.

Tabel 7

Tabulasi Silang Kebiasaan Mengkonsumsi Makanan Kariogenik Dengan Kejadian Karies Di MI AL-Hidayah Madiun Tahun 2019

\begin{tabular}{|c|c|c|c|c|c|c|}
\hline \multirow{3}{*}{$\begin{array}{l}\text { Kebiasaan mengkon-sumsi } \\
\text { makanan kariogenik }\end{array}$} & \multicolumn{4}{|c|}{ Terjadiya karies gigi } & \multirow{2}{*}{\multicolumn{2}{|c|}{ Total }} \\
\hline & \multicolumn{2}{|c|}{ tidak } & \multicolumn{2}{|c|}{ ya } & & \\
\hline & $\mathrm{n}$ & $\%$ & $\mathbf{n}$ & $\%$ & $\mathbf{n}$ & $\%$ \\
\hline Tidak & 14 & 27,5 & 0 & 0 & 14 & 27,5 \\
\hline Kadang-kadang & 0 & 0 & 9 & 17,6 & 9 & 17,6 \\
\hline Sering & 0 & 0 & 28 & 54,9 & 28 & 54,9 \\
\hline Jumlah & 14 & 27,5 & 37 & 72,5 & 51 & 100 \\
\hline
\end{tabular}

Sumber :Data Primer Diolah, 2019

Hasil penelitian tabel 6 bahwa anak yang tidak mengkonsumsi makanan kariogenik dan tidak terjadi karies gigi sebanyak 14 siswa (27,5\%), anak yang kadang-kadang mengkonsumsi makanan kariogenik dan tidak terjadi karies gigi yaitu tidak ada dan anak yang sering mengkonsumsi makanan kariogenik dan tidak terjadi karies gigi juga tidak ada. Anak yang tidak mengkonsumsi makanan kariogenik dan terjadi karies gigi tidak ada, anak yang kadang-kadang mengkonsumsi makanan kariogenik dan terjadi karies gigi sebanyak 9 siswa (17,6\%) dan anak yang sering mengkonsumsi makanan kariogenik dan terjadi karies gigi sebanyak 28 siswa $(54,9 \%)$. 
Tabel 8

Hasil analisis korelasi Spearman

Kebiasaan Mengkonsumsi Makanan Kariogenik Dengan Kejadian Karies

Skor konsumsi makanan kariogenik $\quad \mathrm{r}=0,860$

$\mathrm{p}<0,000$

$\mathrm{n}=51$

\section{Sumber : uji korelasi spearman}

Hasil uji statistik spearman untuk menganalisa hipotesa alternatif yang menyatakan ada hubungan kebiasaan mengkonsumsi makanan kariogenik dengan kejadian karies gigi diperoleh nilai $\mathrm{p}$ $=0,000 \quad(\mathrm{p}<\alpha=0,05) \mathrm{H} 1$ diterima yang berarti ada hubungan kebiasaan mengkonsumsi makanan kariogenik dengan kejadian karies pada anak usia sekolah di MIAL-Hidayah Madiun. Tingkat keeratan hubungan antara hubungan kebiasaan mengkonsumsi makanan kariogenik dengan kejadian karies gigi di ketahui dalam kategorik sangat kuat. $(\mathrm{r}=0,860)$ (Arikunto, 2010).

Menurut Arisman (2002), mengkonsumsi makanan kariogenik dengan frekuensi yang lebih sering akan meningkatkan kemungkinan terjadinya karies dibandingkan dengan mengkonsumsi dalam jumlah banyak tetapi dengan frekuensi yang lebih jarang. Hal ini sejalan dengan penelitian Khotimah (2013) dengan judul penelitian "faktor - faktor yang berhubungan dengan kejadian karies gigi pada anak usia 6-12 tahun di SD", responden yang sering mengkonsumsi makanan kariogenik dan tidak mengalami karies gigi sebanyak $5(21,5 \%)$, dibandingkan dengan responden yang jarang mengkonsumsi makanan kariogenik dan tidak mengalami karies gigi sebanyak 15 (42,9\%).

Hal ini disebabkan karena permen dan snack memiliki harga yang murah serta terdapat berbagai macam rasa dan warna yang menarik untuk anak-anak. Hasil ini sama dengan penelitian yang dilakukan sebelumnya oleh Worotitjan pada anak Sekolah Dasar tahun 2013, yang menyatakan bahwa anak-anak Sekolah Dasar lebih menyukai makanan manis dan memiliki berbagai macam rasa. Pada penelitiannya, persentase konsumsi makanan kariogenik terbesar adalah snack pada frekuensi 2-3 kali perhari sebanyak 20 anak dan permen pada frekuensi $>3$ kali perminggu sebanyak 19 anak.12 Berdasarkan penelitian yang dilakukan oleh Kartikasari, konsumsi makanan kariogenik pada frekuensi $3-6$ kali perhari dapat meningkatkan angka kejadian karies. Riset Kesehatan Dasar (RISKESDAS) tahun 2013, menyatakan bahwa sebanyak 53,1\% rata-rata penduduk Indonesia usia $\geq 10$ tahun mengkonsumsi makanan/minuman manis $\geq 1$ kali dalam sehari. Tingginya frekuensi konsumsi makanan kariogenik tanpa diikuti dengan kesadaran dalam menjaga kesehatan mulut merupakan penyebab terjadinya karies pada anak usia sekolah.

Hasil penelitian ini menunjukan bahwa kejadian karies dan konsumsi makanan kariogenik masih tinggi pada anak usia sekolah di MI AL-Hidayah Madiun. Namun penelitian ini memiliki keterbatasan yaitu hanya melihat hubungan konsumsi makanan kariogenik dan kejadian karies, sehingga perlu dilakukan penelitian lebih lanjut untuk menganalisis factor penyebab kejadian karies pada anak usia sekolah.

\section{KESIMPULAN}

Responden paling sering mengkonsumsi makanan kariogenik seperti permen dan es cream. Ada hubungan kebiasaan mengkonsumsi makanan kariogenik dengan kejadian karies pada anak di Mi AlHidayah Madiun. Diharapkan siswa setelah mengkonsumsi makanan kariogenik berkumur dan menggosok gigi agar tidak terjadi karies gigi serta melakukan pemeriksaan gigi setiap 6 bulan sekali.

\section{DAFTAR PUSTAKA}

Aflah, R. dan Sufriani. (2018). Gambaran Menggosok Gigi Dan Mengkonsumsi Makanan Kariogenik Pada Anak Usia Sekolah di SDN 54 TAHIJA Banda Aceh. Volume 3, Nomor 1.

Arikunton S (2006). Prosedur Penelitian Suatu Pendekatan Praktik. Jakarta: Rineka Cipta.

Arisman, M.B. (2002). Gizi dalam daur kehidupan. Jakarta: EGC. Hal 42.

Budiman J. (2009). Buku Pintar Kesehatan Gigi Dan Mulut. Jakarta : EGC.

Dahlan, S. (2009). Statistik Untuk Kedokdetar dan Kesehatan. Edisi 4. Jakarta : Salemba Medika.

Dahlan, S. (2014). Statistik Untuk Kedokdetar dan Kesehatan. Edisi 6. Jakarta : Salemba Medika. 
Dewa, I gede.(2014). Gambaran Perilaku Menggosok Gigi pada Siswa SD Kelas Satu dengan Karies Gigi di Wilayah Kerja Puskesmas Rendang Karangasem Bali Oktober 2014.E-ISSN: 25033638, prin ISSN: 2089-9084 ISM VOL. 6. 1, MEI-AGUSTUS, HAL 23-33.

Dewi, C. dan Oktiawati, A. (2015). Teori Dan Konsep Tumbuh Kembang Bayi, Todler,Anak Dan Usia Remaja. Maret 2015.

Dharmawati, A. 2015. Konsumsi SoftDrinkMengakibatkanKerusakanGigi. Jurnal ilmu gizi. Volume 6, No 1, Februari 2015.

Dinkes RI. (2012). SAP(Satuan Acara Penyuluhan) Perawatan Gigi.

Firlana, F. (2017). Analisa Mudah Dengan SPSS. Spasi Medika.

Hamid, A Syafitrih.Kundre, Rina.Bataha, Yolanda. (2017). Hubungan Pola Makan Dengan Karies Gigi Pada anak Kelas IV Usia 8-9 Tahun Di Sd Negeri 126 Manado Lingkungan 1 Kleak Kecamatan Malayang Kota Nomor2.

Kurdaningsih , Septi Viantri. (2017). Hubungan Kebiasaan Menggosok Gigi Dengan Timbulnya Karies Gigi Pada Anak Usia Sekolah Di SDN 135 Palembang. Volume 1, nomor 1, februari 2018.

Kusumaningrum, N. (2018). Kebiasaan Mengonsumsi Makanan Kariogenik, Menggosok Gigi Malam, Kejadian Karies Gigi, Dan Status Gizi Di SDN Kleco Ii Surakarta. Universitas Muhammadiyah Surakarta. Novemver 2018.

Khotimah, K. (2013). Faktor - faktor yang berhubungan dengan kejadian karies gigi pada anak usia 612 tahun di SD Negeri 03 Karangayu Semarang.

Mastuloh, I dan Anggita, N. 2018. Metode Penelitian Kesehatan. 2018.

Ningsih, U, S. Restuastuti, T. Endriani, R. (2016). Gambaran Pengetahuan Dan Menyikat Gigi Pada Siswa-Siswi Dalam Mencegah Karies Di SDN 005 Bukit Kapur Dumai. Jok Fak Volume 3 No.2 Okotber 2016.

Notoatmojo, S. 2010. Metodologi Penelitian Kesehatan. Jakarta : Rineka Cipta. Notoatmojo, S. 2018. Metodologi Penelitian Kesehatan. Jakarta : Rineka Cipta.

Nursalam, 2017. Metode Penelitian Ilmu Keperawatan. Jakarta : Salemba Medika.

Pamungkas, R, Adan Usman, M, A. 2017. Metodologi Riset Keperawatan. Jakarta.

Rahayu S ${ }^{1}$, dan Luki I. (2018). Hubungan Mengkonsumsi MakananKariogenik Dan PolaMenyikat Gigi Dengan KejadianKaries Gigi Pada AnakUsiaSekolah. Vol. 6 no. 2 november 2018.

Sari, A, S. 2014. Hubungan Kebiasaan Menggosok Gigi Dan Timbulnya Karies Gigi Pada Anak Usia Sekolah Kelas 4-6 di SD Ciputan Tangerang Selatan Provinsi Banten Tahun 2014. Skripsi Fakultas Kedokteran Dan Ilmu Kesehatan Universitas Islam Negeri Syarif Hidayatullah Jakarta.

Sariningsih, E. (2014). Gigi Busuk Dan Poket Periodontal Sebagai Fokus Injeksi. Jakarta: Gramedia.

Soetjiningsih. 2012. Perkembangan Anak Dan Permasalahannya dalam Buku Ajar Ilmu Perkembangan Anak Dan Remaja. Jakarta: Sagungesto.

Suprajitno. 2008. Asuhan Keperawatan Keluarga: Aplikasi Dalam Praktik, Jakarta: ECG.

Sufrianildan Aflah, R. 2018. GambaranMenggosok Gigi DanKebiasaan Mengkonsumsi Makanan Kariogenik Pada Anak Usia SekolahDi Sdn54Tahija BandaAceh. Vol 3, no 1.

Suwelo, I.S. (1992). Petunjuk Praktis Sistem Merawat Gigi Anak di Klinik. Jakarta: EGC. Hal 78.

Tarigan, R. (2013). Karies gigi edisi 2. Jakarta: Penerbit Buku Kedokteran EGC. Hal 15-90

Widya, Y. (2008). Pedoman Perawatan Kesehatan Anak. Bandung : Penerbit Yrama Widya.

Wong, D.L. (2008). Pedoman Klinis Keperawatan Pedriatik Edisi 4. Jakarta : EGC.

Worotitjan L, Mintjelungan CN, Gunawan P. Pengalaman karies gigi serta pola makan dan minum pada anak Sekolah Dasar di desa Kiawa Kecamatan Kawangkoan Utara. Jurnal e-GiGi. 2013;1(1):5968

Yatim, F. (2015). Gangguan Kesehatan Pada Anak Usia Sekolah. Jakarta : Pustaka Populer Obor. 